werden auf Hämatokrit, Bluthämoglobin und Glukose, Serumharnstoff, Albumin, Gesamtprotein, Calcium, anorganischen Phosphor, Magnesium, Kalium, Natrium, Kupfer, Eisen und gesamte Eisenbindungskapazität geprüft. Die wichtigen Faktoren, welche die Konzentration dieser Blutbestandteile beeinflussen, nämlich Herde, Jahreszeit, Laktationsstadium und Alter der Tiere, werden in Betracht gezogen und die normalen Variationsbrieiten, die in diesem Institut verwendet werden, sind angegeben. Untersuchungen an drei verschiedenen Haltungssystemen in einem Viehbestand lassen darauf schliessen, dass der Stoffwechselprofiltest eine verbesserte Kontrolle des Gesundheits - und Ernährungszustandes bei wachsenden Tieren ermöglichen könnte.

Eine weitere Anwendung könnte der Test bei der Wahl von besserem Zuchtvieh finden. Es wird bewiesen, dass schwarzbunte (British Friesian) Bullen mit hohen ZeitgennossinnenVergleich für Milchleistung auch hohe Hämoglobinkonzentrationen in ihrem Blut aufweisen. Besonders frohwüchsige Jungtiere haben oft hohe Albumin —, Hämoglobin - und Glukoseblutkonzentrationen, wogenen ihre Kaliumkonzentrationen niedrig sind. Die Signifikanz dieser Befundewird in ihrer Beziehung zu einer allgemeinen statistischen Bewertung der Vererbungsschätzwerte von Blutbestandteilen beim Rind besprochen.

\title{
ESTIMATES OF THYROID ACTIVITY AS PREDICTORS OF BREEDING VALUE FOR MILK PRODUCTION IN CATTLE
}

\section{Ø. Joakimsen, - Department of Animal Genetics and Breeding, Agricultural University of Norway As - NLH, Norway.}

The presented data show a positive correlation between thyroxine degradation rate of bulls and milk yield of their daughters obtained under field conditions. The correlation exists both when the thyroid activity is estimated on young bulls as well as on mature bulls. In the two groups where the thyroxine degradation rate where measured on I4 and 80 young bulls the estimated correlations were .25 and .16, respectively. The same parameter ranged between .14 and .47 in four groups where the thyroid activity was measured on 97 mature animals. The correlations indicate a genetic connection between the two traits, because no environmental covariances should be expected with the present experimental procedure. It expected accuracy in the evaluation of thyroid activity and milk production is taken into account the genetic correlation between the two traits are estimated to be .22 to .57 . It is however, concluded that a general application of thyroid activity measurements as selection criteria should be avoided until information about genetic variation in maintainance requirements and its relation to thyroid activity is available.

\section{HORMONAL INDICATORS OF REPRODUCTIVE MERIT}

\section{R. B. LANd. - A.R.C. Animal Breeding Research Organisation, West Mains Road, Edinburgh,} EH9 3JQ., United Kingdom.

Physiological studies of breeds of sheep of differing prolificacy have shown that these differencies are related to the release of luteinizing hormone (LH). The conclusion that this relationship extended to both sexes and to young animals indicated that it might be possible to base selection for prolificacy on the concentration of $\mathrm{LH}$ in male lambs. The concentration is however variable, and two possibilities are being considered to reduce this variation : the LH response to $\mathbf{L H}$ releasing hormone, and testis growth. Both the concentration of LH-following LHRH and the rate of testis growth have been found to be greater in breeds of high prolificacy than in those of low prolificacy. These relationships are now being studied within breeds, and their use as criteria for genetic selection for female reproductivity assessed.

\section{FACTORS INFL,UENCING PLASMA AMINO ACIDS IN CAL,VES}

\author{
F. Pirchner, W. Stöcki and W. Weiser. - Dept. Animal Breeding, Univ. Technology Munich, \\ Dept. Chemistry, Vienna Veterinary School.
}

Sixty Plasma-Amino-Acid levels (PAA) determinations were made on 36 male twin calves of Austrian Braunvieh. The statistical analysis showed that nutritional differences milk replacer : roughage + concentrate had minor, but age differences greater effects upon PAA levels. In 